\title{
Governance Model of Badunsanak Campaign in the Election of the Regional Heads in West Sumatra
}

\author{
M. Fachri Adnan ${ }^{1 *}$ and Hasbullah Malau ${ }^{2}$ \\ 12, Department of Public Administration, Faculty of Social Science, Universitas Negeri Padang \\ *Corresponding author.Email: fachriadnan@fis.unp.ac.id and hasbullahmalau@fis.unp.ac.id
}

\begin{abstract}
The background of this article presents the conceptual governance of campaigns with the thought of electoral good governance in Regional Head Elections, so that regional head election campaigns are safe, peaceful, democratic, open, and avoid conflict. Although efforts have been made to anticipate conflicts, such as the concept of making a collective agreement on the Badunsanak regional election, these have not been implemented and are still within the limits of political euphoria. However, campaign governance in West Sumatra still occurs, such as before the implementation of the campaign the installation of campaign props was carried out, disobedient rules, frequent nowitness voting, ineffective oversight, and off- schedule campaign activity. The main objective of this research is to identify a specific instrument for the "Badunsanak" campaign governance model in the regional elections in West Sumatra so that the model can later be applied to regional head elections in West Sumatra and regions in Indonesia. The conclusion of this paper refers to the findings of various campaign governance model instruments based on Badunsanak cultural values as Geneology values of the Minang community; mutual respect, belonging, respect, tolerance, mutual, openness, feeling, brotherhood and brotherhood integrated with the principles of electoral good governance; Transparency, Integrity, Independence; Impartiality; Efficiency; and service orientation, as a model for campaign governance in regional head elections in West Sumatra and regions in Indonesia.
\end{abstract}

Keywords: Governance and the Badunsanak Campaign

\section{INTRODUCTION}

The issues discussed in this paper refer to the conceptual limitations in the campaign governance literature, especially "Badunsanak" in the Regional Head Election in West Sumatra, so that it is in line with electoral good governance thinking so that a safe, peaceful, domocratic, open regional election campaign can be carried out. , and avoid conflict.

The purpose of this article is to highlight all the problems that may arise related to campaign governance in the regional head elections to ensure that campaign governance is appropriately implemented in West Sumatra so that there is no conflict in the community. In addition, the limitation of the problem is closely related to the instrument of traditional Minang cultural values "Badunsanak" in campaign management in the Regional Head Election in West Sumatra. Although efforts have been made to anticipate conflicts, such as the concept of making a collective agreement on the Badunsanak regional election, these have not been implemented and are still within the limits of political euphoria.

However, campaign governance in West
Sumatra still occurs, such as before the campaign to install campaign props was carried out, not obeying the rules, voting often without witnesses, ineffective supervision, and campaign activities outside of schedule.

The main objective of this research is to identify a specific instrument for the "Badunsanak" campaign governance model in the regional elections in West Sumatra, so that the model can later be applied to regional head elections in West Sumatra and regions in Indonesia.

Good regional head election governance is a means of realizing democracy in regional head elections. However, based on the results of previous research, the implementation of campaign governance in various regions including West Sumatra is problematic. According to Dewi $(2015)^{1}$, the implementation of the campaign for regional head candidates has not been able to uphold justice, the cost of nominating is often violated. Meanwhile, Mutiarini, Diyah, et al $(2011)^{2}$, stated that there are weaknesses in regional head elections including; the occurrence of money politics, elite capture, political fraud, and 
leakage of the local budget. Then Putri and Adnan's research $(2019)^{3}$, shows the ineffective supervision of the campaign and voting for the regional head elections of Padang City. The supervisory committee's authority is also limited to sanctioning campaign violations.

Nabilla's research $(2020)^{4}$, shows that there are many violations in the implementation of the campaign in Kota Padang, Kota Pariaman, and Kota Padang Panjang in 2018. including; the installation of campaign props is not in accordance with the rules, supervision has not been effective yet, and campaign activities are outside the schedule. Meanwhile, Febratama $(2020)^{5}$, shows various violations in the governance of the use of campaign funds, including; violation of the law on campaign fund management, transparency and accountability of campaign fund management. Based on these problems, it is necessary to carry out research on "Campaign Governance Model" Badunsanak "in the Election of Regional Head Election for Regional Heads in West Sumatra". This model is expected to be used as input for solutions so that a safe and peaceful regional election campaign can be implemented so as to avoid conflicts in the implementation of regional head elections. This research was planned for 2 years. The first year focused on finding a governance model for the "badunsanak" campaign in the regional head elections in West Sumatra. The second year focused on the implementation of the "badunsanak" campaign governance model in the regional head elections in West Sumatra.

The Badunsanak Campaign Governance Model in the Regional Head Election of WestSumatra Province in realizing the implementation of good Regional Head Elections (electoral good governance), which is able to provide accuracy of facts, interpretations, functions and roles in the governance of the Badunsanak campaign in regional head elections in the campaign phase there were many violations.
Moreover, at the campaign stage, regional head elections are very prone to conflicts between parties and supporters of candidate pairs. To overcome potential conflicts and reduce violations at the campaign stage, it is necessary to find a solution by integrating local cultural values (local wisdom) in the implementation of the campaign. One of the local cultures that can be integratedin the implementation of the campaign is the Badunsanak Campaign concept. Therefore, research on the "Badunsanak" Campaign Governance Model in the West Sumatra Regional Head Election "needs to be done. As a solution to realizing good Regional Head Elections.

\section{RESEARCH METHODS}

Based on the objectives of this research, the flow of this research will find the Badunsanak Campaign Governance Model in the Regional Head Election of West Sumatra Province in realizing the implementation of good and democratic Regional Head Elections (electoral good governance) in West Sumatra, as local wisdom that is maintained and used by the Minangkabau community of West Sumatara (1) This qualitative, research approach to describe, analyze and interpret matters relating to the principles of transparency, integrity, independence; Impartiality; Efficiency; and orientation to services is examined specifically, in detail in order to reveal phenomena in the field (2) Research locations, carried out at the KPU of West Sumatra Province, Bawaslu of West Sumatra Province and Supporting Political Parties and the people of West Sumatra) (3) Research Informants, (a) apparatus KPU of West Sumatra Province (b) Bawaslu apparatus of West Sumatra Province and (c) Supporting Political Parties in the West Sumatra community) (4) Qualitative data analysis techniques use an interactive model of analysis as Matthew B. Miles. A. Michel Huberman and Johnny Saldana, $(2014: 33)^{6}$

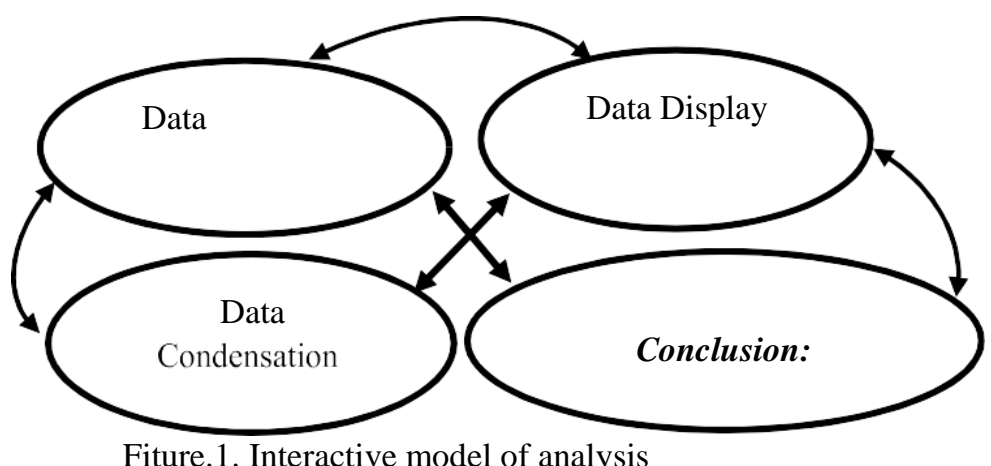

Fiture.1. Interactive model of analysis 


\section{RESULTS AND DISCUSSION}

\section{Governance Model Of Badunsanak Campaign In The Election Of Regional Heads In West Sumatra}

Every region in Indonesia has a different culture. On the basis of these differences, each region must be differentiated according to its regional culture. Likewise, the implementation of campaign governance is determined by the ability of the organizers and other stage holders to accommodate and absorb the cultural values prevailing in the regions to support the success of regional head elections, especially in campaign implementation. For West Sumatra Province, "the regional head election campaign model integrated with local culture (local wisdom) is known as the" Badunsanak Campaign ". The integration of local wisdom values in campaign implementation is very important considering that regional head elections cannot be separated from the regional context.

The leadership model in Minangkabau is three component that call in Minangkabau culture

" tungku tigo sajarangan". It means that leaders in Minangkabau culture consist of ninik mamak as custom cultural leader, ulama as religious leader, cerdik pandai as intelektual leader. The status of the leaders often said in the Minang proverb " ditinggikan sarantiang, didahulukan salangkah". It means that status of leader in the Minangkabau culture is not so hight. The leader of Ninik mamak so importand in Minangkabau. Each clan has it own ninik mamak to manage his clan members. Each nagari in Minangkabau has the institution of Ninik Mamak that call "Kerapatan Adat Nagari" So niniak mamak in Minangkabau play an important role in regulating the nagari, especially anak kemenakan. Meanwhile, in reality now, local governments such as mayors and governors rarely involve and include niniak mamak. In Agam, for example, the Muspida Plus was formed where niniak mamak were included, but nowadays due to the friction that will occur is very vulnerable, especially in the community, all factors can cause problems in the implementation of regional elections simultaneously. If the organizers of the elections are not good at organizing the problems that arise, it will trigger conflict. Pilkada campaigns are not only about posting pictures / billboards / attaching photos of candidates, but must always include niniak mamak, then niniak mamak later the figures who take a step first in decision making. So it can be concluded that the newest model of the election campaign which is effective is the badunsanak campaign because if it is related to the concept of local wisdom, it refers to the Law Article 18b paragraph 2 where the state recognizes that Minangkabau is a special area in its territory and its uniqueness of its customs. Therefore, the ones who will work hard for it are Bawaslu and KPU. Do not choose a brother to be a leader if you feel that you are not worthy and do not adhere to customs and religion, because religion plays an important role in determining a good leader.

The idea of Regional Head Election of Badunsanak (Pilkada Badunsanak) has often been raised in the holding of regional head elections in West Sumatra such as the 2008 Padang City Pilkada and the 2010 Fifty Cities Regional Election. The concept of the Pilkada Badunsanak is basically an elite commitment and agreement that is formalized in the implementation of the Pilkada so that each pair of candidates is ready to accept defeat as part of the democratic process (Asrinaldi 2010: 28) ${ }^{7}$. Apart from that, according to Husni Kamil Malik 'Pilkada Badunsanak' which has been echoed in West Sumatra for the past two periods, is still relevant to be maintained and has become a topic of discussion at the national level and many regions have made it a reference in the implementation of Pilkada (Padang Media.com 9 September 2015 But the motto or jargon of "Badunsnak Pilkada" has not been clearly formulated what it means and how it will be implemented. This philosophy is felt to give a soul to the Minangkabau people in carrying out the Pilkada. According to Nusyirwan $(2014)^{8}$ badunsnak culture in Minangkabau society means siblings based on the ties of one people (lineageclan or fictitious kinship. Furthermore, Nusyirwan $(2014)^{8}$ the concept of badunsanak also means one-blood ties (geneological) which means a very strong brotherly bond in maintaining the maternal lineage (matrineal). Politically, pilkada badunsanak is still considered the jargon of elite politics to build harmony safe, but still has a competitive spirit (Asrinaldi 2010) ${ }^{7}$ so it is necessary to design what the real is. Therefore it is necessary to design a campaign model for badunsanak that is safe and peaceful by taking into account the principles of election management with integrity, imbued with the spirit of brotherhood so that violations and vertical / horizontal conflicts can be avoided.

Based on the description of this research, the Badunsanak Pilkada has emerged since 2005, but to this day there is no clear concept and concrete implementation so that until today the KPU does not use the tekline anymore because the jargon cannot be implemented. If it has been formulated into a concept that can be implemented, it will definitely be used and adopted by the KPU because it is part of the culture that can encourage the quality of democracy / support from local culture to strengthen democracy.

Prior to the existence of the badunsanak 
concept in Minangkabau, regional head elections were carried out with the concept of top down and button up (selected by the center later downward), in other words the center determines where each candidate is placed. Long before that, the leadership in Minangkabau highly upheld local wisdom so that there was very little such thing as shock. The closeness between the elements of the leader is very strong and close, a high sense of friendship, and good cooperation so that no one feels put down by one another. So badunsanak has a feeling of being siblings and willing to share with one another, not feeling like a rival but one family.

The concept of badunsanak in Minangkabau already has provisions according to Minangkabau customs. As for the 5 binders of badunsanak people in Minangkabau (1) Because of their descent or called the blood rope (2) Sahino Samalu, in the Minang proverb "shame can't be divided, the tribe can't be factored". That is, we should not humiliate other people, especially if we are dunsanak and if someone spreads hateful speech to others it means that they have cut the rope of badunsanak or in Islam it means breaking the ties of friendship. If we insult a brother or a dunsanak it is the same as insulting ourselves. For example, in the case of Mulyadi, the case with Markiaswanto, two leaders who quarreled with each other even though they were fellow Agam people. (3) Pandan Pakubur Graves in Minang are often called ustano / jirek / pandam. If there are Minang people who die, they are buried in the same grave, because the function of the grave is for ranji (the structure of the lineage from oldest to youngest) or known as ranji nan takubua. If associated with syara 'or religion, Minang people have the belief that after the resurrection day in Padang Masyar, we will rise up with our family or dunsanak so we don't have to look around. Minang people don't want to do complicated work, but they immediately think carefully about the future to come. The composition of the graves has been arranged in such a way as to make it easy to arrange the ranji (3) Sabarek sieve, in the minang proverb "if there is an ado baban that is barek kito pikua basamo, if someone is light it is kito jinjiang basamo".So there is nothing difficult to do when living in Minangkabau because they always live together by cooperating and helping each other. Gotong royong comes from the Sanskrit language, namely "gotong" is to lift and "royong or raya" means together (4) Saharato sapusako, meaning that the Minang people have one shared treasure and one heirloom, each leader has one heirloom and it is divided together.

The Badunsanak campaign governance principles as Minang Kabau traditional cultural values are (1) democratic, to carry out the campaign democratically. There is a Minang proverb which says "lamak deck crew, katuju dek urang" means to keep other people's feelings and tolerance, or in other terms "grace raso jo pareso, raso cut up, pareso cut down" (2) good and true, understand the meaning badunsanak properly and correctly. The word badunsanak comes from the word "kinsman" which can be interpreted as a very close brotherhood. In Arabic it is called "ukhwah", which means that people who are badunsanak / preach are people who still have family / relatives who are not hostile. (3) Trust, take care of other people's feelings during campaigning, must not offend others. This means that the leader only delivers his vision and mission without dropping or underestimating the opponent's vision and mission (4) Human Relations or Ukhua, maintaining the relationship "batali is not putuih, things are not broken". This means that after the election or campaign is over we will maintain good relations and friendship (5) with each other as if, maintaining a "sasakik samati" relationship, meaning that if someone is sick we will also feel pain (6) Please help each other, maintain the relationship "kaba baiak baimbau, kaba hurry baambuan ", meaning that fellow contestants help each other and do not show the attitude of competitors (7) forgive each other, if someone hurts each other then they must forgive each other. (8) Responsibility, maintain the relationship" lost replaced, sumbiang dititik ". If any of the successful teams destroy the banners of other candidates, they must be replaced again. The success team is actually a person whose function is to socialize candidates to the community (9) Freedom to express opinions, express their own opinions but still listen to the opinions of others. For example: maybe in the vision and mission of other people there are things that we can make as examples but change with our own words (10) Ability, realizing our weaknesses, and acknowledging the superiority of people (11) common goals over personal interests, willing to sacrifice a little feeling for the sake of achieve common goals (12) vision and mission, turn on our lights as brightly as possible, but don't turn off the lights of people or both our work area / "basupadan rice fields jo the ground". Like a rice field, if one flow of water is blocked, the rice field in another place will not flow (13) honest and fair, Must be honest and fair.

So it can be understood that the concept of badunsanak actually has the same purpose and the same taste. This means that in the election campaign all have the same goal, namely to become a leader, but we still have to guard against hostility and hate speech. 


\section{CONCLUSIONS}

The conclusion of this paper, refers to the findings of various campaign governance model instruments based on Badunsanak cultural values as geneological values of the Minang community; mutual respect, belonging, respect, tolerance, mutual, feeling, brotherhood and brotherhood integrated with the principles of electoral good governance; Transparency, Integrity, Independence; Impartiality; Efficiency; and service orientation, as a model for campaign governance in regional head elections in West Sumatra and regions in Indonesia. The Badunsanak campaign governance principles as Minang Kabau traditional cultural values are (1) democratic, to carry out the campaign democratically. There is a Minang proverb which says "lamak dek awak, katuju dek urang" means to keep other people's feelings and tolerance, or in other terms "grace raso jo pareso, raso cut up, pareso cut down" (2) good and true, understand the meaning badunsanak properly and correctly. The word badunsanak comes from the word "kinsman" which can be interpreted as a very close brotherhood. In Arabic it is called "ukhwah", which means that people who are badunsanak / preach are people who still have family / relatives who are not hostile. (3) Trust, take care of other people's feelings during campaigning, must not offend others. This means that the leader only delivers his vision and mission without dropping or underestimating the opponent's vision and mission (4) Human Relations or Ukhua, maintaining the relationship "batali is not putuih, things are not broken". This means that after the election or campaign is over we will maintain good relations and friendship (5) with each other as if, maintaining a "sasakik samati" relationship, meaning that if someone is sick we will also feel pain (6) Please help each other, maintain the relationship "kaba baiak baimbau, kaba hurry baambuan ", meaning that fellow contestants help each other and do not show the attitude of competitors (7) forgive each other, if someone hurts each other then they must forgive each other. (8) Responsibility, maintain the relationship" lost replaced, sumbiang dititik ". If any of the successful teams destroy the banners of other candidates, they must be replaced again. The success team is actually a person whose function is to socialize candidates to the community (9) Freedom to express opinions, express their own opinions but still listen to the opinions of others. For example: maybe in the vision and mission of other people there are things that we can make as examples but change with our own words (10) Ability, realizing our weaknesses, and acknowledging the superiority of people (11) common goals over personal interests, willing to sacrifice a little feeling for the sake of achieve common goals (12) vision and mission, turn on our lights as brightly as possible, but don't turn off the lights of people or both our work area / "basupadan rice fields jo the ground". Like a rice field, if one flow of water is blocked, the rice field in another place will not flow (13) honest and fair, Must be honest and fair.

\section{ACKNOWLEDGMENT}

Acknowledgments, the authors submit to the Institute of Research and Community Service (LP2M) of Universitas Negeri Padang for PNBP research funding in the fiscal year 2020, The author also thanks General Election Commission of West Sumatra Province, general election supervisory agency of West Sumatra Province, Lembaga kerapaatan adat Minang (LKAM), Majelis Ulama Indonesia Provinsi Sumatera Barat (MUI Sumbat) which is the location of this study and thanks to the research team.

\section{REFERENCES}

[1] Dewi, et al. (2015), Menata Ulang Pemilukada MenujuTata Kelola Pemerintahan Daerah Demokratis, Akuntabel, dan Berkelanjutan. Jurnal Penelitian Politik. Volume 12, Nomor 2 Desember, Hal.105-118.

[2] Dyah ,et al. (2011), Analisis Dampak Positif dan Negatif dalam Pemilukada Langsung BagiKualitas Pelayanan Publik di Daerah. Magister Ilmu Pemerintahan, Universitas Muhammadiyah Yogyakarta. Hal. 1-8

[3] Putri, Isra Mulyadi dan Adnan, M.Fachri (2019) ${ }^{3}$, Evaluasi Kinerja Badan Pengawas Pemilu Dalam Mengawasi Pelaksanaan Pilkada Kota Padang Tahun 2018, Journal of Residu,Volume 3, Issue 16, April 2019

[4] Nabilla $(2020)^{4}$, Evaluasi Pelaksanaan Tata Kelola Kampanye, Pemungutan dan Penghitungan Suara pada Pemilihan Kepala Daerah Serentak tahun 2018 di Kota Padang Panjang, Kota Pariaman, dan Kota Padang, Tesis Program Magister Administrasi Publik, FIS, Universitas Negeri Padang.

[5] Febratama, Rezi (2020) $)^{5}$, Evaluasi Prinsip Aturan Hukum, Transparansi dan kuntabilitas Pengelolaan Dana Kampanye Pemilihan Kepala Daerah Serentak Tahun 2018, Tesis, Program Magister Administrasi Publik, FIS, Universitas Negeri Padang.

[6] Huberman dan Saldana, 2014. Research Methods in Quantitative and Qualitative Approaches.M.E. Sharpe, Inc. New York. 
[7] Asrinaldi (2010), "Pemilukada Badunsanak: Menguatkan Demokrasi Elit atau Mendorong Partisipasi Masyarakat?'. Jurnal Analisa Politik, 1 (1) (September).

[8] Efendi, Nusyirwan (2014), Budaya Politik Khas Minangkabau Sebagai Alternatif Budaya Politikdi Indonesia, Masyarakat Indonesia, Vol. 40 (1), Juni 2014, hal. 75-88 